\title{
PENGARUH PEMANFAATAN SUMBER BELAJAR IPS \\ TERHADAP HASIL BELAJAR PADA SISWA KELAS VIII DI SMP NEGERI 29 SEMARANG
}

\author{
Susilo Dewi, Tukidi, Aisyah Nur Sayidatun Nisa \\ Program Studi Pendidikan IPS \\ Susilodewi528@gmail.com
}

\begin{abstract}
The purposes of research are (1) To know the utilization of Social science learning sources by the students; (2) To know the influence of the utilization of Social science learning sources on the learning results of eighth grade in SMP Negeri 29 Semarang. Data analysis for the utilization of Social science learning resources using frequency descriptive, and simple linear regression analysis for the influence of utilization of Social science learning resources on learning results. The results showed that (1) The utilization of Social science learning sources in SMP Negeri 29 Semarang; (2) The influence of the utilization of Social science learning sources on the students learning results. The regression equation is $Y=13.788+1.145 X$ means the increase of learning results on student learning method is positive. The average of the students learning method is 39.38, according to the regression equation, the learning result is 68 (below the KKM).
\end{abstract}

Keywords: Learning Sources, Social Science Learning, and Learning Results

\begin{abstract}
Abstrak
Tujuan penelitian ini adalah (1) Mengetahui Pemanfaatan Sumber Belajar IPS oleh siswa kelas VIII di SMP Negeri 29 Semarang; (2) Mengetahui Pengaruh Pemanfaatan Sumber Belajar IPS Terhadap Hasil Belajar pada siswa kelas VIII di SMP Negeri 29 Semarang. Analisis data untuk pemanfaatan sumber belajar IPS menggunakan deskriptif frekuensi, dan analisis pengaruh pemanfaatan sumber belajar IPS terhadap hasil belajar siswa menggunakan metode analisis regresi linier sederhana. Hasil penelitian menunjukkan; (1) Pemanfaatan sumber belajar IPS pada SMP Negeri 29 Semarang, secara umum dikategorikan sering memanfaatkan sumber belajar IPS; (2) Pengaruh pemanfaatan sumber belajar IPS terhadap hasil belajar pada siswa kelas VIII di SMP Negeri 29 Semarang persamaan regresinya adalah $\mathrm{Y}=13,788+1,145 \mathrm{X}$ yang berarti kenaikan hasil belajar terhadap cara belajar siswa adalah sebesar 1,145 dengan koefisien regresinya positif. Rata-rata nilai cara belajar siswa berdasarkan kuesioner yang diberikan adalah 39,38 sehingga berdasarkan persamaan regresinya dihasilkan nilai hasil belajar sebesar 68 (dibawah nilai KKM).
\end{abstract}

Kata Kunci: Sumber Belajar, Pembelajaran IPS, dan Hasil Belajar 


\section{PENDAHULUAN}

Kemajuan dunia pendidikan menciptakan manusia bermartabat mulia yang memiliki potensi tinggi untuk kemajuan bangsa sehingga dapat meningkatkan mutu pendidikan. Pendidikan merupakan kegiatan yang dilakukan dengan sengaja agar anak didik memiliki sikap dan kepribadian yang baik sesuai dengan Sistem Pendidikan Nasional yang tertuang dalam Undang-Undang No 20 tahun 2003. Guru, orang tua, siswa, maupun pihak sekolah saling bekerja sama dan bertanggung jawab untuk mewujudkan tujuan pendidikan tersebut. Sekolah sebagai lembaga pendidikan merupakan wadah yang tepat dalam mewujudkan tujuan pendidikan yaitu dengan menciptakan peserta didik yang memiliki prestasi belajar yang tinggi di sekolahnya agar mempunyai bekal kemampuan dan keterampilan guna kehidupan di masa datang.

Berdasarkan observasi yang dilakukan peneliti pada siswa di SMP N 29 Semarang selama proses pembelajaran siswa kurang terlatih untuk menemukan, mengembangkan sendiri fakta dan konsep dari materi pembelajaran yang guru sampaikan. Siswa belum mampu mengaplikasikan konsep-konsep yang telah dipelajari di dalam buku paket IPS pada kehidupan sehari-hari, sehingga kemampuan berfikir kritis siswa kurang dapat berkembang dengan baik. Beberapa siswa di SMP Negeri 29 Semarang dalam mengikuti pembelajaran belum sepenuhnya mampu mencerna materi
IPS dengan baik. Guru dalam menyampaikan materi pembelajaran masih menggunakan metode ceramah (teacher centered), proses pembelajaran kurang diminati siswa karena penyajian materi yang monoton, materi pelajaran tidak dikemas secara apik, baik dari segi metode maupun media pengajaran, tidak banyak siswa yang mau bertanya dalam proses pembelajaran, siswa kurang berani mengemukakan gagasan dalam kegiatan belajar.

$$
\text { Purwanto }
$$

keberhasilan belajar siswa dipengaruhi oleh beberapa faktor, yaitu faktor dari dalam diri siswa (intern) dan dari luar diri siswa (ekstern). Faktor dari dalam siswa antara lain: kecerdasan, bakat, minat, motivasi diri, disiplin diri, dan kemandirian, sedangkan faktor dari luar diri siswa dapat berupa lingkungan alam, kondisi sosial, ekonomi, lingkungan sekolah, guru, kurikulum, dan sebagainya, jadi rendahnya hasil belajar siswa dapat disebabkan oleh beberapa faktor yaitu, faktor dari dalam diri siswa merupakan faktor yang penting dalam menentukan keberhasilan belajar, sebab dalam proses belajar sasaran utamanya adalah siswa sebagai objek. Faktor eksternal yang dapat mempengaruhi hasil belajar IPS adalah penggunaan sumber belajar di sekolah, hal ini meliputi sumber belajar tercetak, non cetak, fasilitas belajar, ataupun lingkungan sekolah. Selain itu untuk memperoleh pengalaman dan untuk latihan yang baik diperlukan adanya sumber belajar 
yang baik. Sumber belajar adalah bahan-bahan apa saja yang dapat dimanfaatkan untuk membantu guru maupun siswa dalam mencapai tujuan.

\section{Pemanfaatan sumber belajar dalam pembelajaran IPS}

Pemanfaatan sumber belajar dalam pembelajaran merupakan salah satu upaya guru dalam menciptakan suasana belajar yang inovatif dan tidak terpaku kedalam metode ceramah saja. Adanya berbagai macam sumber belajar, selain membuat siswa tidak cepat bosan juga terdapat hal-hal baru yang membuat siswa lebih tertarik di mata pelajaran tersebut termasuk dalam pelajaran IPS. Hal ini merujuk pada teori definisi menurut AECT (2004) dalam Warsita (2008:17) menyatakan bahwa menggunakan, memanfaatkan, mengelola sumber belajar merupakan bagian dari peningkatan dalam proses pembelajaran yang termasuk teknologi pendidikan. Berdasarkan teori tersebut, tujuannya yaitu untuk memfasilitasi pembelajaran agar lebih efektif, efisien, dan menyenangkan serta meningkatkan kinerja. Pemanfaatan sumber belajar dalam pembelajaran termasuk dalam mata pelajaran IPS merupakan bagian kinerja guru dalam menciptakan suasana belajar yang inovatif yang memanfaatkan kejadiankejadian sosial yang ada di lingkungan sekolah. Hal ini merujuk pada teorinya Sumantri (2001:74), yang menyatakan bahwa Pendidikan IPS merupakan penyederhanaan disiplin ilmu-ilmu sosial, ideologi negara, dan disiplin ilmu lainnya serta masalah-masalah sosial terkait, yang diorganisasikan dan disajikan secara ilmiah dan psikologis untuk tujuan pendidikan pada tingkat pendidikan dasar dan menengah.

\section{Sumber belajar}

Sering kita dengar istilah sumber belajar (learning resources), orang juga banyak yang telah memanfaatkan sumber belajar, namun umumnya yang diketahui hanya perpustakaan dan buku sebagai sumber belajar. Padahal secara tidak terasa apa yang mereka gunakan baik orang maupun benda tertentu adalah termasuk sumber belajar. Sumber belajar ditetapkan sebagai informasi yang disajikan dan disimpan dalam berbagai bentuk media, yang dapat membantu siswa dalam belajar sebagai perwujudan dari kurikulum. Bentuknya tidak terbatas apakah dalam bentuk cetakan, video, format perangkat lunak atau kombinasi dari berbagai format yang dapat digunakan oleh siswa ataupun guru, dengan demikian sumber belajar juga diartikan sebagai segala tempat atau lingkungan sekitar, benda, dan orang yang mengandung informasi dapat digunakan sebagai wahana bagi peserta didik untuk melakukan proses perubahan tingkah laku (Abdul Majid, 2009:170).

\begin{tabular}{lr}
\multicolumn{2}{r}{ Kegiatan mengajar diperlukan } \\
sumber pembelajaran & untuk \\
memperlancar tercapainya tujuan \\
belajar. Sumber pembelajaran dalam \\
Pembelajaran IPS tidak hanya berupa
\end{tabular}


panjangan media di dalam kelas, tetapi memiliki makna yang luas, yang berkenaan dengan hakikat pelajaran IPS, yakni yang erat kaitanya dengan kemasyarakatan atau kehidupan sosial. Apabila diklasifikasikan, sumber pembelajaran dalam IPS dapat berupa media dan lingkungan sosial dengan beragam fenomenanya, termasuk lingkungan belajar siswa. Guru tidak perlu khawatir tentang sumber pembelajaran IPS, karena sumber pembelajaran utamanya sudah termuat dalam buku sumber yang sesuai dengan kurikulum. Hanya yang perlu mendapat perhatian adalah, bahwa sumber belajar tersebut seyogyanya menginformasikan hal-hal yang aktual, karena salah satu sumber belajar dalam PIPS adalah kehidupan sosial itu sendiri (Suprayogi, dkk. 2011:63).

\section{Ilmu-ilmu sosial sebagai sumber dan materi IPS}

Perkembangan ilmu-ilmu sosial telah menyediakan peluang terhadap aplikasi, perhatian tertentu, atau tematik, yang telah membuat ilmu sosial dan sub-ilmunya memiliki ciri dan spesialisasi tertentu. Istilah "ilmu sosial" menunjuk pada kumpulan berbagai disiplin ilmu yang masuk ke dalam rumpun ilmu sosial tersebut. Berbagai disiplin ilmu sosial yang dimaksud adalah: sejarah, sosiologi, ilmu politik, psikologi sosial, filsafat, antropologi, ekonomi dan geografisosial. Masing-masing disiplin ilmu tersebut mempunyai struktur keilmuan yang didalamnya tertata konsep, fakta, generalisasi, dan teori. Hubungan ilmu-ilmu sosial dengan studi sosial atau IPS nampak bahwa ilmu sosial merupakan sumber dan materi IPS, karena ilmu sosial memberikan sumbangan (kontribusi) berupa fakta, konsep, generalisasi, dan teori terhadap IPS unuk dipilih, diramu, dan dipadukan sebagai bahan pembelajaran IPS. Baik ilmu sosial maupun IPS sama-sama mengkaji dan menelaah manusia dengan dunia sekelilingnya, termasuk keadaan sosial yang terus dan selalu berubah atau peristiwa-peristiwa sosial yang terjadi, sehingga keadaan dan peristiwaperistiwa sosial tersebut perlu digunakan sebagai salah satu sumber dan materi pengajaran IPS (Suprayogi, dkk. 2011:40-41).

Sumber belajar merupakan sesuatu yang penting karena dapat turut memperlancar Proses Belajar Mengajar (PBM). Guru bukan satu-satunya sumber belajar, walaupun tugas peranan dan fungsi guru dalam proses belajar mengajar sangat penting. Proses belajar dalam diri siswa akan terjadi baik karena ada yang secara langsung diajar oleh seorang guru atau instruktur dan ada yang tidak secara langsung. Siswa yang tidak diajar langsung, siswa harus belajar aktif berinteraksi dengan media atau sumber belajar yang lain. Guru atau instruktur hanyalah satu dari begitu banyak sumber belajar lain.

Pembelajaran Ilmu Pengetahuan Sosial (IPS)

Pengertian IPS Ilmu Pengetahuan Sosial (IPS) secara sederhana, 
merupakan integrasi antara mata pelajaran Geografi, Sejarah, Ekonomi, Sosiologi, serta mata pelajaran ilmu sosial lainnya. IPS dirumuskan atas dasar realita dan fenomena sosial yang mewujudkan suatu pendekatan interdisipliner dari aspek cabangcabang ilmu sosial yang dibelajarkan di tingkat sekolah dasar dan menengah. Oleh karena itu penjabaran konsepkonsep, pokok bahasan dan sub-pokok bahasan harus disesuaikan dengan tingkat pengalaman dan perkembangan mental anak pada jenjang pendidikan yang bersangkutan (Trianto, 2010:171).

Pelajaran IPS pada jenjang Sekolah Menengah Pertama (SMP) seringkali dianggap sebagai pelajaran yang membosankan dan kurang diminati siswa. Fenomena tersebut dapat disebabkan karena sebagian besar materi dalam pelajaran IPS adalah materi hafalan. Selain itu pelajaran IPS juga sering diartikan sebagai pelajaran yang kurang penting dan cenderung disepelekan oleh kebanyakan siswa di SMP Negeri 29 Semarang. Tujuan diadakannya pembelajaran IPS kepada siswa yaitu agar setiap peserta didik menjadi warga negara yang baik, melatih peserta didik berkemampuan berfikir matang untuk menghadapi dan memecahkan masalah sosial, dan agar peserta didik dapat mewarisi dan melanjutkan budaya bangsanya (Direktorat Pendidikan Lanjutan Pertama, 2004:15). Dalam beberapa disiplin ilmu yang terdapat di mata pelajaran IPS, beberapa materi seperti geografi, ekonomi, sosiologi, dan sejarah maka semakin banyak pula sumber yang dapat dimanfaatkan mengingat materi IPS begitu luas. Oleh karena itu pemanfaatan sumber belajar di SMP pada mata pelajaran IPS sangatlah penting karena selain terdapat banyak materi dan cabangcabang ilmu sosial di dalamnya, maka dikhususkan pembelajaran sangat membutuhkan banyak sumber belajar guna mendukung pembelajaran yang efektif serta menjadikan siswa berperan aktif.

Disiplin ilmu yang terdapat pada mata pelajaran IPS, seperti materi geografi, ekonomi, sosiologi, dan sejarah akan membutuhkan sumber belajar yang bervariasi mengingat materi IPS begitu luas. Oleh karena itu pemanfaatan sumber belajar IPS di SMP Negeri 29 Semarang sangatlah penting karena akan mendukung pembelajaran yang efektif serta menjadikan siswa berperan aktif di dalam proses pembelajaran IPS.

Salah satu indikator tercapainya tujuan pembelajaran dapat diketahui dengan melihat tinggi rendahnya hasil belajar yang dicapai setelah mengikuti proses belajar mengajar. Hasil belajar adalah penilaian yang diperoleh siswa setelah melakukan kegiatan pembelajaran dan berkenaan dengan penguasaan materi yang telah diterima selama pembelajaran berlangsung. Sudaryono (2012:42) mengemukakan bahwa evaluasi terhadap hasil belajar yang dicapai oleh peserta didik merupakan penilaian terhadap hasil 
belajar atau proses belajar tersebut, untuk mengetahui sejauh mana hasil belajar dan proses pembelajarannya dapat dinilai baik.

Hasil belajar adalah perubahan tingkah laku sebagai proses belajar yang meliputi kognitif, afektif, dan psikomotor. Hasil belajar merupakan produk, keterampilan, dan sikap yang tercermin di dalam perilaku sehari-hari siswa (Sudjana, 2002:45). Hasil belajar adalah suatu kegiatan yang telah dilakukan atau dikerjakan baik secara individu maupun kelompok. Dapat disimpulkan bahwa hasil belajar adalah penilaian yang diperoleh siswa setelah melakukan kegiatan pembelajaran dan berkenaan dengan penguasaan materi yang telah diterima selama pembelajaran berlangsung.

Berdasarkan data nilai tengah semester yang peneliti peroleh dari guru mata pelajaran IPS di SMP N 29 Semarang diketahui bahwa hasil belajar siswa terhadap mata pelajaran IPS masih tergolong rendah yaitu 68 dibawah Kriteria Ketuntasan Minimal (KKM). Hal ini, disebabkan karena kurangnya perhatian siswa dalam menerima pelajaran, siswa sibuk dengan aktivitasnya sendiri, berbincang-bincang dengan teman sebangku, mengantuk dan bermain sendiri ketika proses belajar mengajar berlangsung maka dari itu sebagian siswa hanya diam dan tidak mau mengeluarkan pendapat jika ditanya oleh guru. Terkait masalah tersebut maka peneliti tertarik untuk melakukan sebuah penelitian yang mengkaji tentang "Pengaruh Pemanfaatan Sumber Belajar Ips terhadap Hasil Belajar pada Siswa Kelas VIII di SMP Negeri 29 Semarang" .

\section{METODOLOGI PENELITIAN}

Jenis penelitian yang digunakan adalah penelitian deskriptif kuantitatif untuk mengetahui pengaruh pemanfaatan sumber belajar IPS terhadap hasil belajar pada siswa kelas VIII di SMP Negeri 29 Semarang. Objek penelitian yang dijadikan populasi dalam penelitian ini adalah seluruh Siswa kelas VIII SMP Negeri 29 Semarang yang terdidi dari 8 kelas dengan jumlah total 284 siswa. Teknik pengambilan sampel menggunakan teknik simple random sampling. Teknik pengumpulan data menggunakan teknik observasi, kuesioner (angket), dan dokumentasi. Uji Validitas dan Reliabilitas Instrumen menggunakan rumus korelasi product moment sebagai berikut:

$$
\begin{aligned}
& \mathrm{rxy}= \\
& \frac{\mathrm{N}(\Sigma \mathrm{Xy})-(\Sigma \mathrm{X})(\Sigma \mathrm{y})}{\left.\left.\sqrt{\left\{\mathrm{N} \Sigma \mathrm{X}^{2}\right.}-(\Sigma \mathrm{X})^{2}\right)\left(\mathrm{~N} \Sigma \mathrm{y}^{2}-\Sigma \mathrm{y}\right)^{2}\right\}}
\end{aligned}
$$

\section{Keterangan}

rxy = Angka korelasi " $r$ " produk moment

$\mathrm{N}=$ Jumlah Subjek

$\mathrm{X}=$ Skor Variabel $\mathrm{y}$

$\mathrm{Y}=$ Skor Variabel $\mathrm{X}$

$\Sigma \mathrm{X}=$ Jumlah seluruh skor $\mathrm{X}$

$\Sigma \mathrm{y}=$ Jumlah seluruh skor $\mathrm{y}$

$\Sigma x y=$ Jumlah seluruh skor $\mathrm{X}$ dan $\mathrm{y}$ 
Analisis data untuk angket pemanfaatan sumber belajar IPS menggunakan deskriptif frekuensi, dan analisis pengaruh pemanfaatan sumber belajar IPS terhadap hasil belajar siswa menggunakan metode analisis regresi linier sederhana menggunakan rumus sebagi berikut:

Nilai a (konstanta regresi)

$$
=\frac{(\Sigma Y i)\left(\Sigma X i^{2}\right)-(\Sigma X i)(\Sigma X i Y i)}{n\left(\Sigma X i^{2}\right)-(\Sigma X i)^{2}}
$$

Nilai b (koefisien regresi)

$$
b=\frac{\{n(\Sigma X i Y i)\}-\{(\Sigma X i)(\Sigma X i Y i)\}}{\left\{n\left(\Sigma X i^{2}\right)\right\}-\left\{(\Sigma X i)^{2}\right\}}
$$

Persamaan Regresi Linier Sederhana

$$
\mathrm{Y}=\alpha+b X
$$

Keterang:

Y : Hasil belajar siswa

a : Nilai hasil belajar

b : Koefisien regresi

$\mathrm{X}$ : Pemanfaatan sumber belajar siswa

(Sugiyono, 2014:261-262)

\section{HASIL DAN PEMBAHASAN}

Berdasarkan analisis deskriptif frekuensi pada angket pemanfaatan sumber belajar IPS di SMP Negeri 29 Semarang diperoleh hasil bahwa pemanfaatan sumber belajar IPS masuk dalam kategori sering memanfaatkan sumber belajar IPS, yaitu sebanyak 29 siswa $(80,55 \%)$, sedangkan 5 siswa $(13,89 \%)$ masuk dalam kategori jarang memanfaatkan sumber belajar IPS, dan
2 siswa $(5,56 \%)$ masuk dalam kategori selalu menggunakan sumber belajar

\begin{tabular}{|c|c|c|c|}
\hline No & Kategori & $\mathrm{F}$ & $\%$ \\
\hline 1 & Tidak Pernah & 0 & 0,00 \\
\hline 2 & Jarang & 5 & 13,89 \\
\hline 3 & Sering & 29 & 80,55 \\
\hline \multirow[t]{3}{*}{4} & Selalu & 2 & 5,56 \\
\hline & Jumlah & 36 & 100,00 \\
\hline & Rata-rata & & 39,38 \\
\hline
\end{tabular}
IPS.

Tabel 1. Pemanfaatan Sumber Belajar IPS

Sumber : Hasil Penelitian 2018

Tabel 1 menunjukan bahwa hasil dari pemanfaatan sumber belajar IPS yang dilakukan oleh siswa SMP Negeri 29 Semarang secara keseluruhan telah ditentukan. Berdasarkan tabel 4.1 tersebut sebanyak 0 siswa $(0,00 \%)$ yang tidak pernah memanfaatkan sumber belajar IPS, 5 siswa $(13,89 \%)$ jarang memanfaatkan sumber belajar IPS, serta 29 siswa $(80,55 \%) \quad$ sering menggunakan sumber belajar IPS dan 2 siswa $(5,56 \%)$ selalu memanfaatkan sumber belajar IPS.

Pemanfaataan sumber belajar IPS sesuai tabel tersebut secara umum dapat dikatakan bahwa siswa sudah sering menggunakan sumber belajar IPS yang ditunjukkan dengan nilai rata-rata skor hasil kuesioner (angket) siswa sebesar 39,38.

Berdasarkan analisis deskriptif hasil belajar pada mata pelajaran IPS siswa kelas VIII SMP Negeri 29 Semarang diperoleh rata-rata sebesar 68. 
Tabel 2. Perolehan Nilai Hasil Belajar Siswa

\begin{tabular}{ccc}
\hline $\begin{array}{c}\text { Interval } \\
\text { Kelas }\end{array}$ & F & \% \\
\hline $41-50$ & 5 & 13,89 \\
$51-60$ & 9 & 25,00 \\
$61-70$ & 8 & 22,22 \\
$71-80$ & 6 & 16,67 \\
$81-90$ & 7 & 19,44 \\
$91-100$ & 1 & 2,78 \\
\hline Jumlah & 36 & 100,00 \\
\hline
\end{tabular}

Sumber: Hasil Penelitian 2018

Berdasarkan tabel distribusi frekuensi di atas dapat menunjukkan bahwa yang berada pada interval kelas 1 terdapat 5 siswa atau $13,89 \%$, kelas 2 terdapat 9 siswa atau $25,00 \%$, kelas 3 terdapat 8 siswa atau $22,22 \%$, kelas 4 terdapat 6 siswa atau $16,67 \%$, kelas 5 terdapat 7 siswa atau $19,44 \%$, dan kelas 6 terdapat 1 siswa atau 2,78\%. Dari data diatas dapat disimpulkan bahwa yang belum tuntas sebanyak 22 siswa dan yang tuntas ada 14 siswa. Karena KKM pada mata pelajaran IPS adalah 70 , sedangkan untuk rata-rata hasil belajar siswa adalah 68 .

Hasil belajar siswa masuk dalam kategori tuntas, yaitu sejumlah 22 siswa $(61,11 \%)$. Sedangkan sebanyak 14 siswa $(38,89 \%)$ masuk dalam kategori belum tuntas. Setelah dilakukan penelitian dilapangan hal tersebut menunjukkan bahwa sebagian besar siswa memiliki hasil belajar pada mata pelajaran IPS yang belum sempurna karena terlihat hanya 1 siswa $(2,78 \%)$ yang memperoleh nilai ketuntasan yang sangat memuaskan. Sedangkan untuk nilai sikap dan keterampilan diperoleh melalui pengamatan langsung yang dilakukan oleh guru dalam kegiatan pembelajaran maupun diluar kegiatan pembelajaran. Nilai sikap siswa bisa dilihat ketika guru memasuki kelas kondisi dan ketika mengikuti ujian siswa sudah bisa terkontrol, artinya siswa sudah siap dalam mengikuti pembelajaran dan ujian. Sedangkan untuk nilai keterampilan siswa dilihat ketika mengikuti pembelajaran IPS bila dilihat dari para individunya dalam mengikuti proses pembelajaran di kelas sudah mau bertanya pada saat guru menerangkan materi, maupun pada saat kegiatan diskusi berlangsung dan nilai keterampilan siswa juga bisa dilihat ketika mengikuti ujian, siswa mampu menjawab pertanyaan setiap soal yang ada pada lembar jawab dengan jujur dan terampil dalam mengaplikasikan jawaban.

Berdasarkan hasil analisis menggunakan regresi linier sederhana didapatkan persamaan sebagai berikut: $\mathrm{Y}=13,788+1,145 \mathrm{X}$. Persamaan regresi tersebut menunjukkan bahwa nilai konstan regresinya adalah 13,788 dengan koefisien regresi sebesar 1,145. Nilai konstan regresi 13,788 artinya apabila pemanfaatan sumber belajar IPS rendah yaitu 0 (nol), maka hasil belajar siswa yang didapatkan siswa adalah 13,788 (dipengaruhi oleh faktor-faktor lain). Koefisien regresi pemanfaatan sumber belajar IPS nilainya 1,145 artinya apabila pemanfaatan sumber belajar IPS mengalami kenaikan $1 \%$, maka hasil belajar siswa akan mengalami 
peningkatan sebesar 13,788. Koefisien regresi bernilai positif antara pemanfaatan sumber belajar IPS terhadap hasil belajar siswa, semakin tinggi pemanfaatan sumber belajar IPS maka semakin tinggi pula hasil belajar siswa yang didapatkannya. Faktor lain yang mempengaruhi hasil belajar siswa adalah sikap, pengetahuan dan keterampilan.

Hasil analisis menunjukkan bahwa $\mathrm{H}_{0}$ ditolak dan $\mathrm{H}_{\mathrm{i}}$ diterima karena nilai signifikansi $0,032<0,05$ hal ini menunjukkan bahwa ada pengaruh yang signifikan antara pemanfaatan sumber belajar IPS terhadap hasil belajar siswa. Pengaruh ini merupakan pengaruh yang positif, artinya jika pemanfaatan sumber belajar IPS terhadap hasil belajar siswa, semakin tinggi pemanfaatan sumber belajar IPS maka semakin tinggi pula hasil belajar siswa yang didapatkannya.

Berdasarkan pembahasan dapat dikatakan bahwa dengan siswa memanfaatkan sumber belajar IPS dapat membantu siswa dalam mengikuti pembelajaran dikelas. Sedangkan guru dapat mempersiapkan pembelajaran dikelas, dengan mengaplikasikan sumber belajar yang ada pada silabus dan RPP yang dibuat. Memanfaatkan buku paket, guru, dan lingkungan sebagai sumber belajar IPS, siswa diharapkan memiliki motivasi yang tinggi dalam mengikuti pembelajaran IPS dikelas. Selain memiliki motivasi yang tinggi siswa juga mampu meningkatkan hasil belajarnya yang meliputi nilai pengetahuan, sikap, dan nilai keterampilan. Dengan kata lain ada pengaruh pemanfaatan sumber belajar IPS tehadap hasil belajar pada siswa kelas VIII di SMP Negeri 29 Semarang.

\section{SIMPULAN DAN SARAN}

Berdasarkan hasil penelitian dan pembahasan mengenai pengaruh pemanfaatan sumber belajar IPS terhadap hasil belajar pada kelas VIII di SMP Negeri 29 Semarang dapat disimpulkan sebagai berikut: (1) Pemanfaatan sumber belajar IPS pada SMP Negeri 29 Semarang, secara umum dikategorikan sering memanfaatkan sumber belajar IPS didasarkan pada indikator pemberian motivasi oleh guru, pemanfaatan buku paket IPS, media/metode yang guru gunakan, respon siswa ketika pembelajaran IPS berlangsung, pemanfaatan lingkungan, menggunaan media sosial sebagai sumber belajar, dan pengaruh sumber belajar terhadap hasil belajar siswa. (2) Pengaruh pemanfaatan sumber belajar IPS terhadap hasil belajar pada siswa kelas VIII di SMP Negeri 29 Semarang persamaan regresinya adalah: $\mathrm{Y}=$ $13,788+1,145 \mathrm{X}$ yang berarti bahwa kenaikan hasil belajar terhadap cara belajar siswa adalah sebesar 1,145 dengan koefisien regresinya positif. Rata-rata nilai cara belajar siswa berdasarkan kuesioner yang diberikan adalah 39,65 sehingga berdasarkan 
persamaan regresinya dihasilkan nilai hasil belajar sebesar 68 (dibawah nilai KKM). Saran yang diberikan yaitu: Siswa hendaknya mampu memanfaatkan sumber belajar IPS yang tepat sesuai dengan materi, sehingga akan menghasilkan hasil belajar yang maksimal pada mata pelajaran IPS. Guru memberikan kesempatan bagi siswa untuk berkreasi dan aktif dalam kegiatan pembelajaran untuk menghasilkan hasil belajar yang optimal yang sesuai harapan. Pihak sekolah hendaknya mampu menyediakan dan atau melengkapi fasilitas sekolah yang dapat digunakan siswa sebagai sumber belajar pada mata pelajaran IPS.

\section{DAFTAR PUSTAKA}

Majid, Abdul. 2009. Perencanaan Pembelajaran Mengembangkan Standar Kompetensi Guru. Bandung: PT Remaja Rosdakarya.

Masykur. 2015. Peningkatan Motivasi dan Hasil Belajar pada Materi Proses Persiapan Kemerdekaan Indonesia Melalui Kolaborasi Model Pembelajaran Student Team Achievement Division dan Time Token (Kelas VIII A SMP Negeri 3 Pekalongan). Dalam Jurnal Harmony, Vol. 2 No. 1, Hal. $65-75$. Semarang: UNNES.

Nisa, Aisyah Nur Sayidatun, dkk. Pelaksanaan Pembelajaran IPS Berbasis Keunggulan
Lokal dalam Upaya Membangun Keterampilan Sosial Mahasiswa Pendidikan IPS. Dalam Jurnal Refleksi Edukatika. Vol. 6. No. 2. Hal. 172-179.

Purnomo, Arif, Dkk. 2016. Model Pembelajaran Ilmu Pengetahuan Sosial (IPS) pada Materi Kontroversi (Controversy Issues) di Sekolah Menengah Pertama (SMP) Kota Semarang. Dalam Jurnal Penelitian Pendidikan (JPP), Vol. 33 No.1, Hal.13-25. Semarang: UNNES.

Purwanto. 2002. Evaluasi Hasil Belajar. Yogyakarta: Pustaka Pelajar.

Slameto. 2010. Belajar dan faktorfaktor yang mempengaruhinya. Jakarta: rineka cipta.

Sudaryono. 2012. Dasar-dasr Evaluasi Pembelajaran. Yogyakarta: Graha Ilmu.

Suprayogi, dkk. 2011. Pendidikan Ilmu Pengetahuan Sosial. Semarang: Widya Karya.

Trianto. 2010. Mendesain Model Pembelajaran Inovatif Progresif. Jakarta: Kencana Prenada Media Grup.

Undang-Undang Republik Indonesia Nomor 20 Tahun 2003 Tentang Sistem Pendidikan Nasional. 
Visminah, P dan Maheswara Rao.ch. 2016. The role of Audio Visual Aids In Teaching and Learning English Language. Intenasional Journal of
Scientific Research. Vol 5 Issue

Warsita, Bambang. 2008. Teknologi Pembelajaran Landasan dan Aplikasinya. Jakarta : PT Asdi Mahasatya. 